\title{
SELF ASSESSMENT FOR HIGHER LANGUAGE LEARNERS' AUTONOMY
}

\author{
${ }^{1}$ Gita Mutiara Hati ${ }^{2}$ Wisma Yunita ${ }^{3}$ Anggun Citra Sari Dewi \\ 1,2,3 Universitas Bengkulu
}

Corresponding email: gitamutiara@unib.ac.id

\begin{abstract}
The objective of this research is to describe how the use of self-assessment could improve learners' autonomy. This study employed an action research design involving freshmen of English Education Study Program University of Bengkulu as the subject of the research. This action research was conducted in the Intensive English Course. The cycle of research consisted of plan, action, observation, and reflection. The cycle consisted of fifteen meetings covering four themes of materials. During the meetings, students were instructed to do self-assessment guided by the instructor after they have finished learning each theme. The indicator of success for this research was at least $25 \%$ students were categorized as having Very High level of autonomy, while the rest were at High level of autonomy. To measure the level of learners' autonomy, a questionnaire was used. The questionnaire covers nine aspects of autonomy with the total fifty items. It was given to the subject at the end of the cycle. From the analyzed data, it was found that after only conducting one cycle of the action research, the indicator of success in this research was achieved. Hence, there was no need to continue it to the second cycle. From the result, $30 \%$ of students were categorized as having Very High Learning Autonomy.
\end{abstract}

Keywords: English language learners, learners' autonomy, self-assessment

\section{INTRODUCTION}

Learning in a university will be very different from learning at the high school level. The main difference is in the learning system, where at the college level applies the semester credit system. In this system, besides face-to-face learning, students are also given structured and independent assignments. The face-to-face learning process in university at this time adopts a studentcentered learning approach, which is student-centered learning. It means that the learning that takes place is not only in the form of lectures by lecturers, but more to activities that involve students in learning. Students must be more active in finding information related to the materials to be studied and be 
actively involved in every activity that has been designed by the lecturer. In addition to the face-to-face learning process, students are also required to be active in reading and seeking information related to the completion of structured and independent assignments given by the lecturer.

Discussions about active learning cannot be separated from discussions about autonomous learning. Learners who are always active will tend to have good learning achievements (Sanitchai \& Thomas, 2018), and will develop their independence in learning (learner autonomy) as well as have a good ability to learn (Cambridge-Community, 2017). The term learner autonomy was originally introduced by Holec in 1981 as a person's ability to be responsible for their learning (Holec, 1981). He also added that the ability to be responsible is not an innate ability, but needs to be acquired either through "natural" ways or through formal learning that is designed in such a way. In other words, learner autonomy is a person's ability to take responsibility for their own learning and this ability is not an innate ability but is acquired either through informal or formal means. According to the definition given by Little (1991), learner autonomy is basically a learner's psychological relationship with the learning process and content in which there is the ability to reflect critically, make decisions, and act independently. Thus, learners who have high autonomy learning have a high desire to realize the things they want and enjoy the freedom to determine their own goals to be achieved (Begum, 2018).

However, along with the times, the term learner autonomy has developed more broadly and is often associated with many practical terms such as individualized learning, self-instruction, self-access, computerassisted language learning, collaborative learning, project work, and selfdirected learning (Gholami, 2016). These terms appear and are used by different experts according to the development of the learning approach. However, one thing in common is that these terms focus on forming active learners who can take control and be responsible for the success of their own learning.

Learner autonomy means that learners are fully responsible for what they learn and how they learn it. According to Richards (n.d.), independent learners must be directly involved in deciding what they want to achieve in learning, determining ways and tools that help them learn, and reflecting and evaluating what they have learned. Independence in learning makes the learning process more personal and focused because learning is based on what is needed and what makes learners interested, which in the end, independent learners will get better learning outcomes.

Learner autonomy has undoubtedly brought many benefits to learners. Thus, it is very important to try to encourage learners to become people who have a high learning autonomy. The two main reasons why learner autonomy 
needs to be developed are proposed by Begum (2018), namely: first, if learners are actively involved in the learning process, they can become more effective and efficient learners because they will be more focused and more active in their learning. Second, the success of learning activities cannot be separated from the learners' view of themselves and their desire to learn. If they are more proactive in participating in the learning process, then there is no doubt that they have good motivation. Good motivation is believed to bring learners to success in achieving their goals.

In relation to foreign language learning, learner autonomy gives a very big role. In learning foreign languages, both learners and teachers believe that it takes a long time to master the foreign language well. Thus, it is not enough to learn language only in the class, but also need a learning process outside the classroom (Najeeb, 2013). To be able to learn well outside the classroom context, it requires a high level of autonomous learning in order to get maximum learning outcomes in more effective ways.

Especially for students who take expertise in the field of language, autonomous learning is considered needed, because they are expected to have better target language skills than students who take other areas of expertise. This also applies to students of the English Language Education Study Program. As prospective English teachers, they are required not only to have professional competence related to mastery of their field of expertise, but also to have high learning autonomy. In the end, good learning autonomy will make them a teacher who can encourage their students to have good learning autonomy as well. Not only that, teachers candidates who have good learning autonomy will tend to be life-long learners (Yurdakul, 2017).

But in fact, based on teaching experience more than ten years in the English Education Study Program, FKIP UNIB, there are still many students who are still not active in lectures and independent learning, moreover having autonomy learning. This is especially the case for first-year students. This tendency occurs probably due to their habit of studying in high school, which is still carried over to college. They are still waiting more for what the teacher will convey, rather than actively seeking information related to the material to be studied. If this is ignored, it will be difficult to improve students' learning autonomy which is feared that it will have an impact on the low achievement of learning outcomes and even mastery of English. For this reason, a way is needed to improve learner autonomy of English Education Study Program students starting from first year students, especially in the Intensive English course.

This Intensive English course was chosen because students learn four language skills (listening, reading, speaking writing) and language components (vocabulary and structure) in an integrative and more intensive manner. This course weighs 6 credits, which proves that students are required 
to have near-perfect command of the English language. The results of this course have a huge impact on the success of the advanced language skills course. For this reason, autonomy learning is very important to be developed through this course so that they get maximum learning outcomes and are able to master English very well and be able to follow advanced courses well.

One way that is considered appropriate in increasing student learner autonomy taking Intensive English courses is by implementing selfassessment. Self assessment is an assessment technique that is actively carried out by learners themselves. It is a form of assessment in which learners independently make choices, choose learning activities, and plan how to use the time and learning resources they have (O'Malley \& Pierce, 1996). In self assessment, learners reflect and self-evaluate the quality of their learning outcomes, determine the extent to which they have achieved their learning targets, and identify their own strengths and weaknesses in their learning outcomes (Andrade \& Du, 2007). Thus, self-assessment can be a major element in increasing learner autonomy (Gholami, 2016).

Self assessment is closely related to the formation of learner autonomy because the definition of learner autonomy itself states that learners are able to reflect and evaluate what they have learned (Richards, n.d.). In addition, self-assessment encourages students to be able to identify their learning progress so that it can motivate them to further develop themselves (Spiller, 2012). In terms of language learning, self-assessment helps students monitor their level of success in achieving certain language tasks or skills (Gardner, 2000). According to Gardner, by implementing self-assessment, students will receive feedback on the effectiveness of the learning strategies they have used so far. Thus, self assessment is very suitable to be applied in increasing learner autonomy.

Previous relevant research that has been done is Mazloomi \& Khabiri (2016). The results of his research show that the writing ability of Iranian students has improved after the experiment was conducted using selfassessment. Second, research by Mardiyah (2018) shows that autonomy in learning improves the reading ability of Mochammad Husni Thamrin University students in Jakarta. Third, research by Hafidz (2018) also proves that learning autonomy is effective at increasing accuracy in writing essays. The three studies link self-assessment and learning autonomy with increased proficiency in language skills.

So far, no research has been found that aims to improve learner autonomy using self-assessment in Bengkulu. A similar study was conducted by Gholami (2016), who conducted experiments to find out the effects of self and peer assessment on learner autonomy and language proficiency of Iranian students. The study proposed this time is more about action research, namely applying self-assessment to improve learners' autonomy. 


\section{METHODS}

Since the aim was to improve students' learning and finding out what works best in the classroom, the design of the research was naturally an action research (Mettetal, 2001). This research followed the cycle model consisted of planning, acting, observing, and reflecting. This cycle could be repeated if at the reflecting stage there is no improvement as seen from the achievement of the indicators of success. If the indicators of the success of this research are met, then there is no need for a further cycle, or in other words the research can be stopped. Particularly for this this research, it was first planned for one cycle consisting of sixteen meetings in approximately five weeks. To determine whether or not the cycle be continued, the criteria of success were set. Considering the nature of the students, the action cycle would be categorized successful, hence the cycle is stopped, if at least $25 \%$ of the subjects were in the level of Highly Autonomous level.

\section{Subject}

The subjects involved in this study were the first-year students of English Language Education Undergraduate Study Program in University of Bengkulu with the total thirty-three students. The research was conducted in the Intensive English course at odd semester Academic Year 2020/2021. Since the course has six credits in a semester, and was scheduled three meetings a week.

\section{Instruments}

The instruments used for this research were self-assessment forms, field-note sheets, and a learning autonomy questionnaire. Self-assessment forms were given to students after they have completed each theme of learning. Since there were four themes, the assessment forms also consist of four sets. The items in the self-assessment forms were statements showing the ability of particular competencies learned in each theme. Students were asked to respond with the answer Yes, Need Minor Improvement, or No, Need major improvement. Field-note sheets were used to keep all the notes about what happened during the learning process and during the discussions after the students have filled in the self-assessment forms. Meanwhile, the learning autonomy questionnaire used in this study was the adaptation from the one used by Gholami (2016). His study used forty-four items questionnaire based on nine dimensions related to language learning, while there were six additional items for this study with similar dimensions. The other adaptation was the Likert scale used in this study. Different from Gholami's study which used five-scale options, this study used four-scale options (Always True, Mostly True, Rarely True, Never True) in order to avoid neutral responses. 


\section{Data Analysis Procedures}

The data gathered from the self-assessment form and the field note were analysed qualitatively. Meanwhile, the data collected from the questionnaire were analysed quantitatively using simple descriptive statistics by calculating the average value of all answers from all question items in the questionnaire. Since the instrument used four-point Likert Scale, an interval of 0.75 was used for the description of learning autonomy. Hence, the data analysis divides the individual's scores into four levels of autonomy (Pimentel, 2019): Highly Autonomous (3.28-4.00), Autonomous (2.52-3.27), Barely Autonomous (1.762.51) and Dependent (1.00-1.75). The analysis result from the questionnaire were used to determine whether or not the cycle of the action research could be stopped.

\section{FINDINGS}

Since this is an action research, the discussion will focus more on the process or the action during the research rather than the final result. As for the result, the indicator of success for this research was already achieved at the end of the first cycle. Hence, it can be concluded that the research could be stopped; the cycle did not need to be continued to the next cycle.

Table: 1 Learner Autonomy Level

\begin{tabular}{ccccc}
\hline No & Score & Autonomy Level & Number of students & Percentage (\%) \\
\hline 1 & $1.00-1.75$ & Dependent & 0 & 0 \\
2 & $1.76-2.5$ & Barely Autonomous & 0 & 0 \\
3 & $2.51-3.25$ & Autonomous & 23 & 70 \\
4 & $3.26-4.00$ & Highly Autonomous & 10 & 30 \\
\hline \multicolumn{2}{c}{ Total } & 33 & 100 \\
\hline
\end{tabular}

It could be seen from Table 1 that 30\% students are categorized as Highly Autonomous and the rest $70 \%$ students belong to Autonomous learner. It actually exceeded the criteria of success which were set for $25 \%$. From this result, the cycle of the research could be stopped. The actions taken during the research have shaped the student's autonomy into Autonomous and Highly Autonomous. The good news is that no students categorized into either Barely Autonomous or Dependent.

The data from the table was used to determine the success of the action. However, since action research is a kind of a quest in which the teachers examine their educational practice for knowledge about how to improve (Ferrance, 2000), the findings will be presented in details of what happened during the research. 


\section{Planning}

Activities carried out in the planning stage include developing learning strategies, compiling lesson plans and preparing learning tools (such as media, materials and tools, observation instruments), preparing selfassessment forms, preparing learner autonomy questionnaire, field note sheets, and establishing a research schedule.

For the first cycle, it was decided that the total number of meetings would be 16 meetings; with 12 meetings for the learning process and four meetings for self-assessment activities. Each self-assessment activity was done upon completing each theme of the learning materials. The teaching and discussions were the role that the main author took since it was her class. The other team members helped a lot with providing ideas with the preparations as well as observing the lessons.

\section{Acting}

At this stage, the learning processes were carried out as has been prepared in the planning step. Since real face-to-face interactions were not allowed due to Covid-19 situation, the lessons were conducted online both synchronously via Zoom Meeting or Google Meet and asynchronously through e-learning platform provided by the university. Hence, all the instructions, materials, and media were all uploaded to the e-learning site.

The lessons were theme-based learning materials with a total of four themes for this first cycle. Each theme was resolved in three meetings. During the meetings, various types of activities available on the e-learning were employed. They are Discussion Forum, Direct Chat, Assignment, and Quiz. By the Discussion Forum, the students post comments as replies to the teacher's questions or instructions. The students could give replies to their friends' comments as well. At the end of the activity, the teacher could see how well the students responded to the instructions or the discussion topics. For Direct Chat, students and the teacher could interact synchronously in written form, just like a regular online chat application. Assignment activity was used to give students individual activities. The responses to the assignments could be either directly written on the site or sent as attachments. Meanwhile Quiz was used to give exercises and test items with different types of question forms.

When they have completed one theme, the next meeting was used for students to fill out the self-assessment form provided in the e-learning site. Students immediately respond or provide answers to questions on the selfassessment form given directly to the e-learning. After filling out the form, a virtual meeting was conducted in order for the teacher and students discuss what they had learned from the materials. Besides, the meeting was also used 
for the teacher to further confirm what the students have responded on the self-assessment form.

The virtual meetings were conducted via either Zoom Meeting or GMeet. On each meeting, the teacher used the information gathered from the self-assessment form to be the issues to discuss. The advantage of using the e-learning when giving self-assessment form to the students is that the students' responses could directly be analysed by the system.

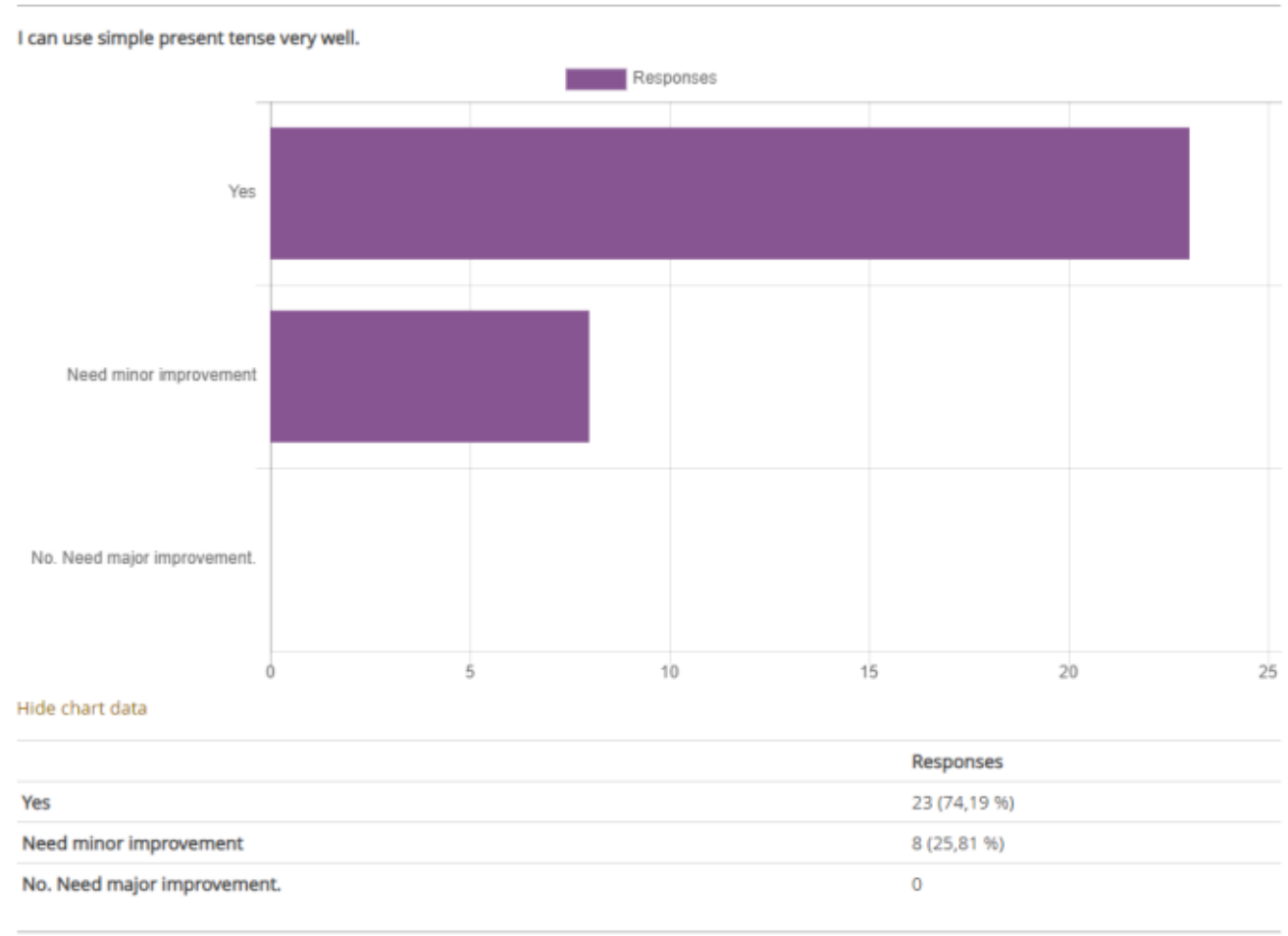

Figure 1: Sample Response from Self-Assessment Form

Figure 1 shows the sample response from the self-assessment form given to students after they have completed Theme 1. The statement of the selfassessment is "I can use simple present tense very well." It can be seen that 23 students $(74.19 \%)$ assessed themselves that they can use simple present tense, while the other 8 students thought that they still need minor improvement on the use of simple present tense. Based on this fact, during the virtual meeting the teacher gave slight review on the simple present tense to the students. The students were also asked to make simple present tense sentences. In doing so, the reliability of the data from the self-assessment form could be confirmed.

In addition, without pointing out which students still needed minor improvement, the teacher asked in general what problems they countered when they practice using simple present tense. Based on the problems, the students were then asked to brainstorms ideas how to solve those problems. After that the students were asked to make plans about what following 
actions, they could do to improve their learning. This is only the sample of what was done during the virtual meeting which was held after each theme was completed and after students have responded to the self- assessment form.

The discussions and cross-checking the data from the self-assessment form were done in order to make sure whether or not they could assess themselves well. There were four virtual meetings for this purpose in total. On each virtual meeting, the teacher and students had deep discussions talking about what learning problems they faced and always brainstorm ideas of what they could do to overcome them. When the data from the selfassessment item showed that all students responded 'Yes, I can', the discussions were mostly instructions to ask the students do the competency shown in the item. It was for confirming whether they are really able to do that. This way, students might be more cautious and aware when they selfassess themselves.

\section{Observing}

On every meeting, observations toward the learning processes were done. The observations on the learning activities were done by the researcher as the lecturer with the help from two co-researchers. Checking out all the responses the students made towards every instruction given on the e-learning was done during the observations. All important things were written on the field note sheet. Not only important things, all considered as peculiar during the learning processes was also recorded on the field note.

In addition, observations were also conducted during the virtual meetings. All the responses and the interactions between the students and the teacher were recorded and were later assessed during the reflection step.

\section{Reflecting}

This was the time when all the data gathered during the acting and observing step were analysed thoroughly. This is the most challenging step since it involved a very careful analysis and assessment toward various information collected during sixteen meetings.

First, reflecting step focuses on the data from observing step during the teaching and learning processes. Observations were made at each meeting and especially during virtual face-to-face meetings. The results of the analysis from the self-assessment forms are used as topics for discussions when holding virtual face-to-face meetings. The virtual face-to-face meeting was held after students had finished filling out the self-assessment forms so that they could discuss their weaknesses in mastering the materials studied during the previous three weeks. At the time of the first discussion, students still seemed to assess themselves not too deeply. This was found out when 
cross-checking between self-assessment answers and the actual students' performance, there was still a discrepancy. Students who have assessed themselves as capable of mastering certain materials turned out that they have not mastered the materials. Thus, after this kind of discussion, students could be more careful in assessing themselves and filling out the selfassessment for the next unit of learning.

Second activity done in reflecting step was analysing the result of the Learning Autonomy Questionnaire. As has been mentioned previously, the questionnaire was given to students at the end of the cycle through the elearning in which students could directly respond. Table 1 shows the levels of students' autonomy based on their responses to the questionnaire.

Meanwhile, when the result of each item of the questionnaire was observed, six items which stand out were picked: three items which have the score above 3.50 and also three items which have the score below 1.50. Table 2 shows the three items with highest scores, meanwhile Table 3 shows the three items with the lowest scores.

Table 2: The Result of Three Highest Scores

\begin{tabular}{clc}
\hline $\begin{array}{c}\text { Item } \\
\text { Number }\end{array}$ & \multicolumn{1}{c}{ Statement } & Score \\
\hline 3 & When I hear someone talking in English, I listen very carefully. & 3.70 \\
\hline 16 & I believe that I will reach a good level in the English Language. & 3.67 \\
\hline 49 & I like to listen and read in English outside the classroom. & 3.67 \\
\hline
\end{tabular}

Table 3: The Result of Three Lowest Scores

\begin{tabular}{clc}
\hline $\begin{array}{c}\text { Item } \\
\text { Number }\end{array}$ & \multicolumn{1}{c}{ Statement } & Score \\
\hline 7 & I like my teacher to correct my errors when I make a mistake & 1.27 \\
43 & I feel happy when my teacher explains something on the board. & 1.27 \\
29 & I'd like my teacher to identify my weaknesses in my English. & 1.3 \\
\hline
\end{tabular}

\section{DISCUSSION}

The result from this Learner Autonomy Questionnaire actually proves what Gholami (2016) has found out. His study shows that self-assessment gives positive impact on learner autonomy, especially in terms of learners' independency on teacher and classroom. He further argues that it may because learners have changed their attitude toward themselves as active subject in language learning process. In addition, Lesmana \& Rokhyati (2020) also found that by involving students in self-assessment activities, they will be more confident and have a greater sense of responsibility. They further say that by doing self-assessment, students will learn how to take careful look at their weaknesses as well as strengths as a source for them to reflect and improve their learning. 
When the result of each item of the questionnaire was observed, six items which stand out were picked: three items which have the score above 3.50 and also three items which have the score below 1.50 shown in Table 2 and Table 3. From Table 2, three items with highest scores were item 3, 16, and 49. Statement of item 3 is When I hear someone talking in English, I listen very carefully. Score 3.7 means that mostly students answer with either Very True or Mostly True. This statement shows not only the students' readiness in learning, but also students' interest on learning English language. It seems trivial, but as the study by Dangol \& Shrestha (2019)points out, students readiness plays very crucial part to the student' learning achievement. Item 16 deals with students' intrinsic motivation dimension in the Learning Autonomy Questionnaire. It shows very positive responses, meaning that students have a very high motivation to achieve the best for their learning. Having high motivation is not only essential in self-assessment activity, but also undoubtedly is important for successful English learning (Alizadeh, 2016). The third highest score is item 49 which shows that students like to listen and read in English outside the classroom. It is actually not a surprising finding, since students in this generation have much exposures to English on their everyday life. When they consciously deal with English exposures outside the classroom, it means that they independently both acquire and learn English by themselves without having any teacher to be dependent on. It is actually a good finding in today's Covid-19 condition in which students are not allowed to go to school; they are required to learn independently outside the classroom. It is even better that when the students are liking their subject of learning, it is more likely that they will get better achievement (Hude \& Rohmah, 2017; Kpolovie et al., 2014).

Meanwhile, Table 3 shows the three items with the lowest scores. Those three items are showing students dependency toward the role of the teacher. Too much dependency the students have on their teacher may limit their chance to develop their sense of responsibility of their own learning and to do self-assessment. However, the condition shown on those three items may happen because the students are in their first year studying in a university. They have not been accustomed to the life of university where students are expected to be more active and independent (Henri et al., 2018).

\section{CONCLUSION AND SUGGESTION}

This study tries to describe the way of how to implement self-assessment activities in a classroom setting to improve students' learning autonomy through a classroom action research. Based on the reflection, the selfassessment activities that the students do should be discussed and confirmed by the teacher. Students may sometimes not self-assess themselves appropriately, that is why the follow-up discussion is needed. In this kind of 
discussion, the teacher may guide the students to further see and reflect themselves carefully. By doing this kind of self-assessment combined with student-teacher discussion, the students' level of autonomy becomes high. However, though the students' autonomy level has been improved, the activities of self-assessment should not be stopped here. It should be continuously practiced in order to develop and maintain students' autonomy in learning. In the long run, it is expected that the students may become lifelong learners.

\section{ACKNOWLEDGMENTS}

This work was financially supported by the Faculty of Teacher Training and Education, University of Bengkulu under contract No. 9200/UN30.7/HK/2020.

\section{REFERENCES}

Alizadeh, M. (2016). The Impact of Motivation on English Language Learning. International Journal of Research in English Education, 1(1), 1115.

Andrade, H., \& Du, Y. (2007). Student responses to criteriareferenced selfassessment. Assessment and Evaluation in Higher Education, 32(2), 159181.

Begum, J. (2018). Learner Autonomy in EFL/ESL Classrooms in Bangladesh: Teachers' perceptions and practices. International Journal of Language Education, 2(2), 96-104.

Cambridge-Community. (2017). Getting Started with Active Learning. https:/ / www.cambridge-community.org.uk/professionaldevelopment/gswal/index.html

Dangol, R., \& Shrestha, M. (2019). Learning Readiness and Educational Achievement among School Students. The International Journal of Indian Psychology, 7(2), 467-476.

Ferrance, E. (2000). Action Research. The Education Alliance at Brown University.

Gardner, D. (2000). Self-assessment for Autonomous Language Learners. Links $\mathcal{E}$ Letters, 7, 49-60.

Gholami, H. (2016). Self Assessment and Learner Autonomy. Theory and Practice in Language Studies, 6(1), 46.

Hafidz, M. (2018). Learner Autonomy on Essay Writing Accuracy. Jurnal Pendidikan Edutama, 5(1), 9-16.

Henri, D. C., Morrell, L. J., \& Scott, G. W. (2018). Student perceptions of their autonomy at University. Higher Education, 75(3), 507-516.

Holec, H. (1981). Autonomy and Foreign Language Learning. Pergamon Press.

Hude, H. M. D., \& Rohmah, I. F. (2017). Analysis of Student Learning 
Interest, and Student Learning Motivation in Enhancement Student Learning Achievement at School. International Journal of Current Research, 9(10), 58981-58985.

Kpolovie, P. J., JOE, A. I., \& Okoto, T. (2014). Academic Achievement Prediction: Role of Interest in Learning and Attitude towards School. International Journal of Humanities Social Sciences and Education, 1(11), 73100.

Lesmana, N., \& Rokhyati, U. (2020). The Implementation of Doing SelfAssessment in Higher Education. Journal of English Language Studies, 5(1), 60-72.

Little, D. (1991). Learner Autonomy: Definitions, Issues and Problems. Authentik. Mardiyah, M. (2018). Penerapan Pembelajaran Autonomi dalam

Meningkatkan Keterampilan Membaca Text Bahasa Inggris. Jurnal Inovasi Pendidikan MH Thamrin, 2(2), 33-42.

Mazloomi, S., \& Khabiri, M. (2016). The Impact of Self-Assessment on Language Learners' Writing Skill. Innovations in Education and Teaching International, 55(1), 91-100.

Mettetal, G. (2001). The What, Why and How of Classroom Action Research. Journal of the Scholarship of Teaching and Learning, 2(1), 6-13.

Najeeb, S. S. R. (2013). Learner Autonomy in Language Learning. ProcediaSocial and Behavioral Sciences, 70(January), 1238-1242. \%3CGo\%0Ato

O'Malley, J. M., \& Pierce, L. V. (1996). Authentic Assessment for English Language Learners : Practical Approaches for Teachers ". Addison-Wesley Pub. Co.

Pimentel, J. L. (2019). Some Biases in Likert Scaling Usage and Its Correction. International Journal of Sciences, 45(1), 183-191.

http://gssrr.org/index.php?journal=JournalOfBasicAndApplied

Richards, J. C. (n.d.). Learner Autonomy in Language Teaching.

https:/ / www.professorjackrichards.com/learner-autonomy-inlanguage-teaching/

Sanitchai, P., \& Thomas, D. (2018). The Relationship of Active Learning and Academic Achievement among Provincial University Students in Thailand. APHEIT International Journal, 7(1), 47-61.

Spiller, D. (2012). Assessment Matters: Self-Assessment and Peer Assessment. In Teaching Development | Wähanga Whakapakari Ako (Issue February). The University of Waikato.

Yurdakul, C. (2017). An Investigation of the Relationship between Autonomous Learning and Lifelong Learning. International Journal of Educational Research Review, 2(1), 15-20. 